\title{
A Case of Cutaneous Leukocytoclastic Vasculitis Associated with Granulocyte Colony-Stimulating Factor: An Unusual Presentation
}

\author{
Dokyoung Yoon, Hyun Jeong Byun, Se Jin Oh, Ji-Hye Park, Dong-Youn Lee \\ Department of Dermatology, Samsung Medical Center, Sungkyunkwan University School of Medicine, Seoul, Korea
}

Drug-induced vasculitis is an inflammation of small-sized blood vessel caused by the use of drugs. It accounts for approximately $10 \%$ of acute cutaneous vasculitis. Propylthiouracil, hydralazine, and allopurinol have been widely known as causative agents. The most common clinical feature of drug-induced vasculitis is palpable purpura on lower extremities. A 66-year-old Korean female presented with erythematous nodules on upper chest and back. She had been on medication for multiple myeloma. Laboratory results showed neutropenia. After a single injection of filgrastim (recombinant granulocyte colony-stimulating factor), she developed cutaneous lesions with concurrent increase in absolute neutrophil count. A skin biopsy revealed leukocytoclastic vasculitis. After discontinuation of filgrastim injection, her skin lesions disappeared spontaneously.

(Ann Dermatol 32(2) $164 \sim 167,2020$ )

\section{-Keywords-}

Cutaneous, Cutaneous small vessel, Granulocyte colonystimulating factor, Skin, Vasculitis

Received 17 January, 2019, Revised March 29, 2019, Accepted for publication 4 April, 2019

Corresponding author: Ji-Hye Park, Department of Dermatology, Samsung Medical Center, Sungkyunkwan University School of Medicine, 81 Irwon-ro, Gangnam-gu, Seoul 06351, Korea. Tel: 82-2-3410-6578, Fax: 82-2-3410-3869, E-mail: jh1204.park@samsung.com ORCID: https://orcid.org/0000-0002-6699-5202

This is an Open Access article distributed under the terms of the Creative Commons Attribution Non-Commercial License (http://creativecommons. org/licenses/by-nc/4.0) which permits unrestricted non-commercial use, distribution, and reproduction in any medium, provided the original work is properly cited.

Copyright $($ c The Korean Dermatological Association and The Korean Society for Investigative Dermatology

\section{INTRODUCTION}

Granulocyte colony-stimulating factor (G-CSF) is a hematopoietic growth factor with many applications in cancer therapy. Various cutaneous adverse events associated with G-CSF have been reported, including Sweet's syndrome and pyoderma gangrenosum ${ }^{1,2}$. Herein, we present a case of G-CSF induced cutaneous vasculitis with unusual manifestation in a patient with multiple myeloma.

\section{CASE REPORT}

A 66-year-old Korean female presented with erythematous nodules and plaques on upper chest and back. She had been treated with bortezomib (proteasome inhibitor) for multiple myeloma for the past three months. Laboratory investigations showed white blood cell (WBC) count of $2,710 / \mu \mathrm{I}$ and absolute neutrophil count (ANC) of $560 / \mathrm{mm}^{3}$. Due to neutropenia, she had received $300 \mu \mathrm{g}$ of filgrastim two weeks before her visit to our outpatient clinic. Three days after the injection, her laboratory results showed improvement in WBC and ANC count to 8,190/ $\mu$ I and $5,320 / \mathrm{mm}^{3}$ respectively; however, skin lesions started to develop. Multiple, tender, finger-tip to coin-sized red nodules were observed on her upper chest and back (Fig. 1). Skin biopsy on her back lesion showed vessel destruction, fibrinoid necrosis, and infiltration of neutrophils and lymphocytes with leukocytoclasia around small-sized vessels in the upper dermis, suggestive of leukocytoclastic vasculitis (Fig. 2). After discontinuation of both bortezomib and filgrastim, the skin lesions subsided within two weeks.

\section{DISCUSSION}

G-CSF regulates the production of neutrophils within the 
bone marrow. Recombinant G-CSF (filgrastim) is clinically used for the treatment of neutropenia associated with chemotherapy. Reported adverse events include bone pain, splenomegaly, hepatomegaly, thrombocytopenia, osteopenia/osteoporosis, glomerulonephritis, growth and development, and subfertility ${ }^{3}$. Cutaneous manifestations associated with recombinant human G-CSF include Sweet's syndrome and bullous pyoderma ganrenosum ${ }^{1,2}$.

The biopsy result and the fact that our patient developed the skin lesion after the injection of G-CSF raised the possibility of drug-induced leukocytoclastic vasculitis. However, because this histologic findings of vasculitis can also occur as a secondary phenomenon, it was necessary for us to exclude other possibilities.

Sweet's syndrome is one of the most possible causes of neutrophilic dermatoses in cutaneous vascular diseases. Histologic findings include perivascular infiltration of neutrophils in the papillary dermis and various extent of vas-
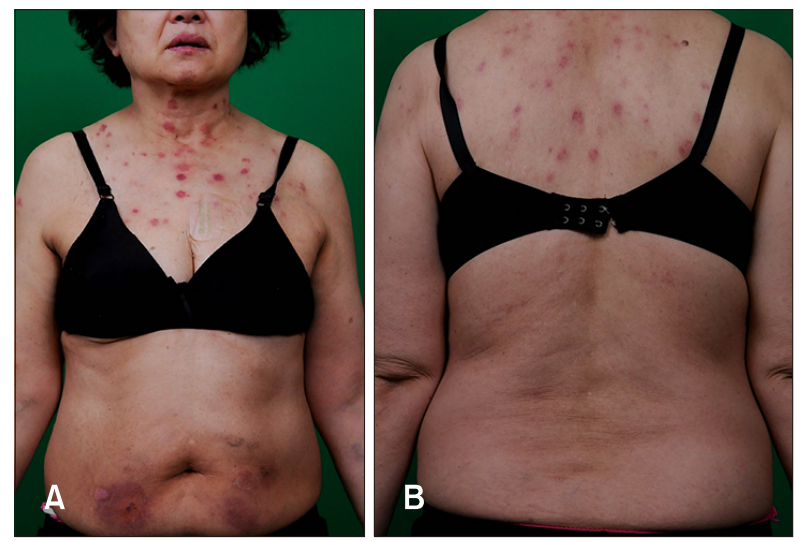

Fig. 1. Multiple tender finger-tip to coin sized red colored nodules on her upper chest $(A)$ and back (B). We received the patient's consent form about publishing all photographic materials. cular damage can be seen. Histologically, Sweet's syndrome was not favored because prominent edema of upper dermis, one of the characteristic features of Sweet's syndrome, was not seen on our specimen. Moreover, our patient did not have fever or involvement of noncutaneous sites, such as eyes, joints, oral mucosa, and visceral organs. Together with the histologic findings and clinical manifestations, we were able to diagnose our patient's skin lesions as leukocytoclastic vasculitis.

PubMed search of literature was made to retrieve publications about cutaneous vasculitis in association with infusion of G-CSF. G-CSF, cutaneous, adverse events, and vasculitis were terms used for the search. We found 18 cases of vasculitis after infusion of G-CSF. However, one study of 12 patients gave limited information (Table 1$)^{4-9}$. Skin lesions developed within two days to one month after receiving G-CSF. Skin biopsy was performed for 17 cases. Of them, 16 cases showed leukocytoclastic vasculitis while the other case showed vasculitis with dermal infiltration of lymphocytes around blood vessel. Affected areas of the skin were described in five cases. All cases involved lower extremities. Three cases affected upper extremities while two cases showed acral lesion concurrently. Similar to the previous case reports described above, skin lesions in the current case developed three days after the injection of G-CSF. In our case, they subsided after stopping the drug. Although drug-induced vasculitis with palpable purpura usually developed on lower extremities in other literatures, tender multiple erythematous nodules showed up on the chest and upper back of our patient.

The mechanism of G-CSF-induced vasculitis is currently unclear, although some possible hypotheses have been proposed. Elsner et al. ${ }^{10}$ who studied neutrophils in patients with congenital neutropenia suggested the involvement of altered fragment constant (FCr) receptor ex-
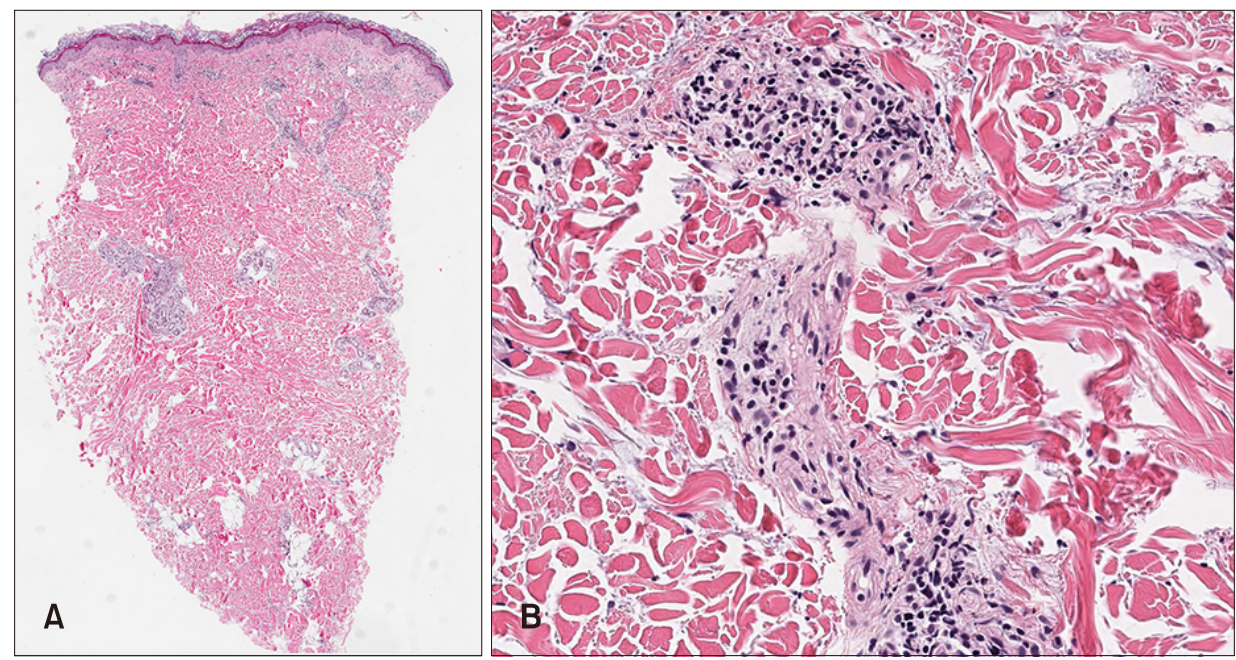

Fig. 2. Histopathological images of skin biopsy. (A) Perivascular inflammatory cells infiltration in the upper dermis $(\mathrm{H} \& \mathrm{E}, \times 40)$. (B) Vessel destruction, fibrinoid necrosis, and neutrophils and lymphocytes infiltration $(\mathrm{H} \& \mathrm{E}, \times 400)$. 
Table 1. Summary of G-CSF induced vasculitis reported previously in literature

\begin{tabular}{|c|c|c|c|c|c|c|c|c|}
\hline Report & $\begin{array}{l}\text { Number } \\
\text { of cases }\end{array}$ & $\begin{array}{l}\text { Age } \\
(y r)\end{array}$ & Sex & Past medical history & Affected area & Histopathology & G-CSF & $\begin{array}{l}\text { Onset of } \\
\text { skin lesion } \\
\text { from G-CSF } \\
\text { infusion }\end{array}$ \\
\hline $\begin{array}{l}\text { Ippoliti } \\
\text { et al. }{ }^{4}\end{array}$ & 1 & 35 & M & Heart transplantation & Lower extremities & $\begin{array}{l}\text { Leukocytoclastic } \\
\text { vasculitis }\end{array}$ & Filgrastim & $4 d$ \\
\hline $\begin{array}{l}\text { El Husseiny } \\
\text { and Mattar }\end{array}$ & 1 & 64 & M & $\begin{array}{l}\text { Chronic lymphatic } \\
\text { leukemia }\end{array}$ & $\begin{array}{l}\text { Ear, Hand, } \\
\text { Lower extremities }\end{array}$ & $\begin{array}{l}\text { Confluent necrosis } \\
\text { in the epidermis } \\
\text { and infiltration of } \\
\text { the dermis with } \\
\text { lymphocytes around } \\
\text { the blood vessels }\end{array}$ & Lenograstim & $2 d$ \\
\hline \multirow[t]{2}{*}{ Kilic et al. ${ }^{6}$} & 2 & 13 & $\mathrm{~F}$ & $\begin{array}{l}\text { Severe congenital } \\
\text { neutropenia }\end{array}$ & $\begin{array}{l}\text { Upper extremities, } \\
\text { Lower extremities }\end{array}$ & $\begin{array}{l}\text { Leukocytoclastic } \\
\text { vasculitis }\end{array}$ & Lenograstim & $1 \mathrm{mo}$ \\
\hline & & 5 & $\mathrm{~F}$ & $\begin{array}{l}\text { Severe congenital } \\
\text { neutropenia }\end{array}$ & $\begin{array}{l}\text { Upper extremities, } \\
\text { Lower extremities }\end{array}$ & $\begin{array}{l}\text { Leukocytoclastic } \\
\text { vasculitis }\end{array}$ & Lenograstim & $4 d$ \\
\hline $\begin{array}{l}\text { Andavolu } \\
\text { and Logan }\end{array}$ & 1 & 30 & M & $\begin{array}{l}\text { Hemophilia } A \\
\text { with arthropathy }\end{array}$ & $\begin{array}{l}\text { Auricles of both ears, } \\
\text { sides of the face, } \\
\text { upper extremities, } \\
\text { and lower extremities }\end{array}$ & $\begin{array}{l}\text { Leukocytoclastic } \\
\text { vasculitis }\end{array}$ & NA & $3 d$ \\
\hline Jain $^{8}$ & 12 & NA & NA & NA & NA & $\begin{array}{l}\text { Leukocytoclastic } \\
\text { vasculitis }\end{array}$ & NA & NA \\
\hline Ito et al. ${ }^{9}$ & 1 & 59 & $\mathrm{~F}$ & $\begin{array}{l}\text { Diffuse large B cell } \\
\text { lymphoma }\end{array}$ & NA & NA & pegfillgrastim & NA \\
\hline
\end{tabular}

G-CSF: granulocyte colony-stimulating factor, M: male, F: frmale, NA: not available.

pression in the pathogenesis of G-CSF-induced vasculitis. Their data showed that patterns of FCr receptor expression of neutrophils from patients with severe congenital neutropenia on G-CSF therapy were signs of in vivo activation of these cells. Because interaction between $\mathrm{FCr}$ receptors and immune complexes can cause release of lysosomal enzymes, altered FCr receptor expression might be associated with cutaneous vasculitis. Elsner et al. ${ }^{10}$ demonstrated that interleukin $1 \alpha$ and tumor necrosis factor- $\alpha$ could stimulate smooth muscle cells of blood vessel walls to synthesize G-CSF by enhancing antibody-mediated toxicity of polymorphonuclear cell.

Cutaneous leukocytoclastic vasculitis is a rare adverse reaction of G-CSF treatment. Because drug-induced vasculitis is indistinguishable clinically from other causes of small vessel vasculitis, it is easy to be misdiagnosed. Patients might be treated improperly, especially when clinical presentation is unusual as described in the present case ${ }^{11,12}$. When the association between G-CSF and leukocytoclastic vasculitis is recognized, the drug should be immediately withdrawn. The eruption may resolve completely without the need of any further treatment. In severe cases, high-dose prednisone treatment may be required ${ }^{11}$.

\section{CONFLICTS OF INTEREST}

The authors have nothing to disclose.

\section{ORCID}

Dokyoung Yoon, https://orcid.org/0000-0002-1769-4921

Hyun Jeong Byun, https://orcid.org/0000-0002-4354-5655

Se Jin Oh, https://orcid.org/0000-0001-7525-4740

Ji-Hye Park, https://orcid.org/0000-0002-6699-5202

Dong-Youn Lee, https://orcid.org/0000-0003-0765-9812

\section{REFERENCES}

1. White JM, Mufti GJ, Salisbury JR, du Vivier AW. Cutaneous manifestations of granulocyte colony-stimulating factor. Clin Exp Dermatol 2006;31:206-207.

2. Ross HJ, Moy LA, Kaplan R, Figlin RA. Bullous pyoderma gangrenosum after granulocyte colony-stimulating factor treatment. Cancer 1991;68:441-443.

3. Cottle TE, Fier CJ, Donadieu J, Kinsey SE. Risk and benefit of treatment of severe chronic neutropenia with granulocyte colony-stimulating factor. Semin Hematol 2002;39:134-140.

4. Ippoliti G, Paulli M, Lucioni M, Lauriola M, D'Armini AM. Leukocytoclastic vasculitis as a complication of recombinant granulocyte colony-stimulating factor therapy in a heart transplant patient. Case Rep Transplant 2014;2014:160407. 
5. El Husseiny NM, Mattar MM. Aggressive cutaneous vasculitis in a patient with chronic lymphatic leukemia following granulocyte colony stimulating factor injection: a case report. J Med Case Rep 2011;5:88.

6. Kilic SS, Mustafayeva S, Ipek K, Adim SB. Leukocytoclastic vasculitis in patients with severe congenital neutropenia. J Trop Pediatr 2010;56:359-362.

7. Andavolu MV, Logan LJ. Leukocytoclastic vasculitis as a complication of granulocyte colony-stimulating factor (G-CSF) -- a case study. Ann Hematol 1999;78:79-81.

8. Jain KK. Cutaneous vasculitis associated with granulocyte colony-stimulating factor. J Am Acad Dermatol 1994;31(2 Pt 1):213-215.

9. Ito Y, Noda K, Aiba K, Yano S, Fujii T. [Diffuse large B-cell lymphoma complicated with drug-induced vasculitis during administration of pegfilgrastim]. Rinsho Ketsueki 2017;58: 2238-2242. Japanese.

10. Elsner J, Roesler J, Emmendörffer A, Zeidler C, LohmannMatthes ML, Welte K. Altered function and surface marker expression of neutrophils induced by rhG-CSF treatment in severe congenital neutropenia. Eur J Haematol 1992;48: 10-19.

11. Goldsmith LA, Katz SI, Gilchrest BA, Paller AS, Leffell DJ, Wolff K. Fitzpatrick's dermatology in general medicine. 8th ed. New York: McGraw Hill, 2012:456.

12. Goeser MR, Laniosz V, Wetter DA. A practical approach to the diagnosis, evaluation, and management of cutaneous small-vessel vasculitis. Am J Clin Dermatol 2014;15:299-306. 